that transcend the personal interests of the particular combination of humans who happen to constitute it at any given moment. Ferdinand Toennies, the founder of the German Sociological Association a 100 years ago, was best known as the translator of Hobbes' Leviathan, a virtual paean to the corporate form (though without having quite severed all biological ties). Long before business firms came to be the dominant corporate entity, churches, school, guilds, universities, and city-states were all so chartered. The mode of reproduction of this artificial entity was distinctly non-biological, and often anti-hereditary-depending instead on formal election and examination. The corporation may in fact be the social entity that makes the sharpest break with humanity's biological origins, while rising to the cyborgian challenge that we 'incorporate' in new ways. In deference to Condorcet, perhaps the state has withered long enough and now needs to be reinvented with these new issues in mind.

\title{
References
}

[1] S. Fuller, Karmic Darwinism: the emerging alliance between science and religion, Tijdschrift voor Filosofie 64 (2002) 697-722.

[2] K. Hayles, How we became posthuman, University of Chicago Press, Chicago, 1999.

[3] A. Hoffman, From heresy to dogma: an institutional history of corporate environmentalism, Lexington Books, San Francisco, 1997.

[4] T.H. Huxley, Evolution and ethics (The Romanes lecture). 1893. Available from: http://aleph0.clarku.edu/huxley/CE9/E-E.html.

[5] P. Singer, A Darwinian Left: politics, evolution and cooperation, Weidenfeld and Nicolson, London, 1999.

[6] B.F. Skinner, Beyond freedom and dignity, Alfred Knopf, New York, 1971.

\section{Making rights from what's left of Darwinism}

\author{
Kirk W. Junker* \\ School of Law, Duquesne University, Pittsburgh, PA 15280, USA
}

\begin{abstract}
The legal, political, and social meaning of the work of Charles Darwin has been claimed as resident to conservative and liberal homes alike. Peter Singer's unique admixture of per-
\end{abstract}

\footnotetext{
${ }^{*}$ Tel.: +1-412-396-1047; fax: +1-412-396-4014.

E-mail address: junker@duq.edu (K.W. Junker).
} 
sonal liberal politics and what may look to be an extremely conservative philosophy of nature expose some over-simplicity in traditional 'right' and 'left' categories. In "Recovering the Left from Darwin in the 21st Century", Steve Fuller provides us with insightful historical and sociological contexts for Singer's challenges. In this article, Kirk Junker takes one aspect of the trajectory 'the notion of natural rights' and examines their social construction, linguistic maintenance, and legal ramifications.

(C) 2004 Elsevier Ltd. All rights reserved.

During a recent local election, Noel Wright raised a series of rhetorical questions in an article regarding the electorate:

Do the political terms "right" and "left" in relation to "centre" any longer have any real meaning for today's educated, well-informed voters? Have voters already moved well beyond the idealized self-portraits with which political parties try to woo them? Is their primary interest now simply COMPETENT government of whatever stripe, serving with maximum efficiency its citizens' practical needs and wishes? In short, has the electorate become deaf to ideological pitches? Consciously or subconsciously, does it now judge government like shareholders judge a corporation - purely by the "bottom-line" economic and social dividends it pays in return for the "shares" they buy in it at the ballot box? [8]

(The incursion of commercial simile into the arena of election politics is itself cause for some concern, but that discussion is for a different day and place.) At the same time that voters may have gone ideologically deaf, it has become common for public office holders and candidates in North America and Europe to remain in a position that the old political spectrum would identify as being ideologically central. These centrists shift only slightly to the right or slightly to the left in response to what the polling of this very same shareholder electorate might predict. These tendencies among public office holders, coupled with the sorts of questions raised by observers of party politics such as Noel Wright, suggest that we ought to be examining what meaning indeed we currently give to the metaphorical uses of "right" and "left" when discussing social politics in general, and when discussing the social policy ramifications of Darwinism ${ }^{1}$ in particular. In addition, these usages carry implications for constructing rights.

\footnotetext{
${ }^{1}$ It is important to distinguish Darwin from Darwinism. As Peter Bowler and others have made clear, much of the theory and political practice done in the name of Darwin springs neither from the hand nor the mouth of Darwin, a fact one can see if one bothers to take the time to read the work. We are reminded for example, that it was Herbert Spencer, not Darwin, who coined the phrase "survival of the fittest" - a series of signs that Spencer believed connected some social needs of the day. Consequently, it was Spencer, not Darwin, who gave us social Darwinism where before there had only been Darwinism [9]. My point is not to vindicate the name of Darwin; in Darwinian fashion, that will take care of itself. Rather, my point is to illustrate that political theory of any stripe can and is fitted to the needs of the day, and calling upon the pedigree of Darwin (or Marx, Ghandi or Aristotle), is to make use of authority to justify one's current position.
} 
In their seminal work, The Social Construction of Reality, Peter L. Berger and Thomas Luckmann discuss reification in a way that is very relevant to the notions of political right and left. They assert that "the central question for sociological theory can be put as follows: how is it possible that subjective meanings become objective facticities?" (italics in original) [10]. During their discussion of institutions, they note that to the extent that persons create institutions, they do so to fulfill particular needs in particular places and times. To this, one might add that these institutions are connected to their creators, and to their creators' needs, by signs. At some point in later generations, however, while the sign and the institution may indeed still exist, either the need as perceived by the creator, or the connection of sign to institution, or both, may be forgotten. Simple examples might include heraldic shields or flags or money. These material items in fact only have value because they act as signs, but for many people, the specific connection of the cross, the star, or the leaping mare is forgotten. Once these connections are lost, we may still support the institution and use the sign, but we will more likely do so because authority, however mild, persuades us to do so. We are not, in these cases of forgotten connections, supporting the institution because we have personally reasoned from the sign to its need. Once the sign is disconnected from the institution, what remains is a coin that has lost its picture (borrowing from Nietzsche), which can therefore no longer serve as a coin, but only as a lump of metal [3]. Currently, "right" and "left" have become very close to being the coin without a picture. Consequently, we might go so far as to say that they are serving as placeholders - placeholders, like empty picture frames, into which the electorate can invest its own idealized self-portrait. Thus, when it comes to finding a political direction for Darwinism, we need first to ask what use and meaning we may have today for "right" and "left" before we locate Darwinism in either place.

According to Berger and Luckmann, once we lose the reasoned connection of institution to need, or of sign to either institution or need, we fall prey to reifying the sign or the institution as though they are undeniable, unalterable, and wholly beyond our own doing. It is here that a point of sociological critique arrives for Berger and Luckmann. Reification signals our relinquishment of the possibility to change that which is changeable. And it would seem precisely at this point of critique that the sociology of Berger and Luckmann has some of the same "exaggerated faith" in the changeability of the human being by which Steve Fuller, in his essay "Recovering the Left from Darwin in the 21st Century" characterizes B. F. Skinner, and later, perhaps Peter Singer. The project of locating and distinguishing the changeable from the unchangeable is not new. Looking at human behaviour from a language perspective, Kenneth Burke characterized the human being as "the symbol-using animal" [4], and concluded that the part of the human that was changeable was his symbolic nature, and the part of the human that was not was his biological nature [5].

While Burke was adding a clear and new distinction to the mix of definitions when he characterized us as "symbol-using animals", the nature of the division with which he concludes - that is, the unchangeability of the biological animal compared to the changeability of the symbol-user-sounds to be not at all new 
today. In fact, now it would seem more radical to place this distinction into question once again. For example, a major theme of the 1999 annual meeting of the British Sociological Association was to ask what the role for sociology had become. At the meeting, Nikolas Rose, now Head of Sociology at the London School of Economics, in commenting upon new research in genetic engineering, noted that in the past, one thought that it was the natural scientists who worked with unchangeable aspects of the human (Burke's biological), and that it was the social scientists who worked with changeable aspects of the human (Burke's symbol-user). But now, said Rose, when thought of in the context of genetic engineering, it looks as if natural science may be in the business of working with things about the human being that are most changeable, and perhaps social science is working with the part of the human being that is less changeable [7]. As Steve Fuller notes, this would indeed be consistent with the exaggerated, if not misplaced faith, that others have had in the ability of humans to change the social behaviour of fellow humans - for example as with Marx, Freud and Skinner. And Singer? Singer's argument, as Fuller states near his conclusion, runs in a different direction. Fuller calls bodily integrity a "perennial right" and an "inalienable baseline of humanity". Rather than accept biological manipulation in animals or humans, Singer wants to extend the perennial right of humans to include animals. If biotechnology has shown us that there is more than $95 \%$ genetic overlap between humans and most animals, and we establish a right to bodily integrity in humans, should there not also be such a right in animals?

For Singer, politicizing Darwin either to the right or the left means to create rights based upon the biological nature of species. This putative material connection, as assumed by others elsewhere, misses an inherent problem regarding the problem of rights - they are human constructs [11]. So the question must be asked, and should be answered-before the discussion can go further: why should we expect any species (in this particular instance of argument, humans) to create institutions, including symbolic institutions like rights, to benefit other species, especially if the same invention or its particular use not only benefits other species, but harms human species as it benefits other species? This question has been raised in the past by those in control of doling out rights, including racial majorities regarding racial minorities, religious majorities regarding religious minorities and men regarding women. In each of these cases, some legal rights to vote, assemble, obtain economic benefit and so forth have eventually been achieved. By comparison, the social recognition and exercise of these rights has always been slower in coming. If one examines the arguments raised to extend rights to these various persons, one finds that they succeed when they are persuasive socially. In contrast, one finds little that is convincing in materialist arguments - especially not with sex and religion, although such arguments were made regarding race, it must be admitted.

Even among the debates of the culture wars and the science wars, no one would have suggested that rights are derived from material nature. Likewise, among the traditional debates between various stripes of legal positivists and natural law adherents, none of the naturalists suggest a physical or material connection of persons to rights. Natural rights theorists may maintain that the rights are with us (or 
with dogs or dandelions or as Fuller notes in his conclusion, with cyborgs) naturally, but that is not to say that there is a material nature connection. If we allow ourselves a short flight of metaphysical fancy, we would see the same connections, and lack of connections, in theories of property ownership. Property ownership by the state, crown or individual exists as a symbolic nexus to the material world, not as a material nexus. To say that I own it is to say that I have the exclusive legal right to exercise control over it. And to be able to exercise my rights and inhibit yours, I need the symbolic power of the collective. My individual right has only the same presence in the world as a single word in a real language does. Without the network of other rights and liabilities, mine alone is nonsense. Without other words and grammar, one word alone is also nonsense. Words do not represent things on a one-to-one naming of the material world. Burke even went so far as to suggest that we might understand the nature of language if we would consider that it is not words that stand for things, but rather that things stand for words, if the words are considered to have a "spirit" that is peculiar to their nature as words. Applied to the concept of rights, that would change the right of equality from "all men are created equal" to "all men are to be considered in terms of ideal equality" [6].

And if one continues to focus not upon the material nature of the being to whom or which rights are to be extended, but rather to the needs and desires of society, here and now, one can better entertain extending rights to other social categories such as unborn generations, for example, by appointing government officials to represent these people, and even to inanimate species $[1,11]$. In answering the question that I raise above, Singer would presumably say that helping other species does in fact ultimately help human species; a connection in keeping with his underlying principle of "X utilitarianism." By arguing for the non-material basis upon which rights can be understood, I am not arguing against Singer's extension of rights to animals or his political utilitarianism. Rather, I would simply point out that historically and currently, we need to remain mindful of the human nature of the institutions, and their changeability, and we must remind ourselves of our reasoning in creating them.

From this point about rights, we are then returned to "right" and "left". In the social construction of knowledge, reifications present themselves to persons as though the institutions, like political right and left, are not humanly created to fulfill a particular need in a particular place at a particular time, but rather, as objectified facticities. Once objectified, these facticities seem to be unchangeable by human action [10]. Applying the admonition of Berger and Luckmann specifically to the politics of Darwinism, we are thus reminded that we created "right" and "left" due to a simple, identifiable and practical necessity of one time and place.

In 1789 the vocabulary of politics took a bit of a turn in France, when the gauche stood up and demanded their droits. As the various parts of French society took their seats in the Constituent Assembly of 1789-91, the Monarchists were seated appropriately on the right side of the hall, from the chair's point of view, and the radicals were seated on the left, separated by a middle group in the center. During the debate on the royal veto, these parties came to be 
known as the Left, Center and Right, with other names expressing assigned seats, so that Montagnards occupied the upper gallery or mountain and the party of the Plains sat on the lower floor. The debate underscored options offered by the left that led toward greater power to the masses and by the right that resisted any loss of power by the elite. From that day on, the terms Left and Right have kept that basic meaning [12].

While Sheasby's narrative is helpful to understand the etymology of the political connotation, it takes some liberties with the construction of meaning. To say that "the terms Left and Right have kept that basic meaning" would be to suggest that these words - these signs - still connect current political institutions with 18th century French Monarchists and their opponents. I would suggest instead that the reified terms serve to frame what Wright called the "idealized self-portraits" of the electorate. And the same can be said of the socio-political right and left as of the party-political right and left. This matters because reifying these idealized selfportraits brings penalties with it. The first penalty that we all pay for this reification is one of form: the implicit acceptance that social politics can only be dialectic. The slogan of the Green Party in Germany for instance has been that they are neither right nor left, but out in front - a phrase later adopted by Bill Clinton according to Sheasby. Here, one is reminded that the aim of this very journal, Futures, is to "promote divergent and pluralistic" futures, not just one seemingly inevitable one. The second penalty that we all pay for the reification is one of substance: the acceptance of pre-determined ethical choices. It is here, that we can ethically analyse social Darwinism, and the reception of Peter Singer's work, and it is here that the ramifications of assumptions regarding the terms "right" and left" can be witnessed.

A practical consequence of considering these distinctions is to lay on the table the ethic produced by Singer's work, not only explicitly, as Singer himself does, but also implicitly. Ethics are not something that we do after we have done something else; ethics are not tools to apply to something that is otherwise outside the scope of ethics. Ethics are the inherent politics or ideologies that are built into the substantive acts themselves. In much of what one might call applied science, normative assumptions are necessary and foundational, but not expressed [2]. Singer's work, and the reception of it in the popular and scholarly press, is a very good example and opportunity to consider many of the normative assumptions inherent in scientific reasoning - in this case, a form of Darwinism. The analysis of this ethic begins with the point of distinguishing the ism from Darwin, so that we must come to terms with admitting our political desires, rather than pretending that we are predetermined by a 19th century naturalist-regardless of his extraordinary talentsto make our current political, social and ethical choices.

\section{References}

[1] C.D. Stone, Should Trees Have Standing?-Towards Legal Rights for Natural Objects, Avon Books, New York, 1975. 
[2] D.A. Brown, American Heat: Ethical Problems with the United States' Response to Global Warming, Rowman \& Littlefield Publishers, Inc, Oxford, 2002.

[3] F. Nietzsche, Ueber Wahrheit und Lüge im aussermoralischen Sinne, Sämtliche Werke. Kritische Studienausgabe, vol. 1, de Gruyter, Berlin, 1980, p. 881.

[4] K. Burke, The Rhetoric of Religion, Beacon Press, Boston, 1961, pp. 40-41.

[5] K. Burke, Permanence and Change, third ed., University of California Press, Berkeley, 1965.

[6] K. Burke, What are the Signs of What? in: Language as Symbolic Action, University of California Press, Berkeley, 1966, p. 364.

[7] N. Rose, Panel discussion remarks at annual meeting of the British Sociological Association, Glasgow, Scotland, April 6, 1999.

[8] N. Wright, Bottom-line' gov't now the goal?, North Shore News, Vancouver, BC, February 22, 1999, Available from http://www.nsnews.com/issues99/w022299/noel-1.html (accessed April 18, 2003).

[9] P.J. Bowler, Evolution: The History of an Idea, third ed., The University of California Press, Berkeley, 2003.

[10] P.L. Berger, T. Luckmann, The Social Construction of Reality: A Treatise in the Sociology of Knowledge, Anchor, London, 1966, p. 18.

[11] R.F. Nash, The Rights of Nature: A History of Environmental Ethics, University of Wisconsin Press, Madison, WI, 1989, p. 143.

[12] W.C. Sheasby, Third parties '96: birds of a feather, Synthesis/Regeneration 10 (Spring) (1996) 10-16, Available from http://www.greens.org/s-r/10/.html (accessed April 18, 2003).

\title{
The Darwinian Left—from myth to intellectual hijacking
}

\author{
Jan Emblemsvåg
}

Stokke Gruppen AS, Division of Production, Håhjem, 6260 Skodje, Norway

Steve Fuller's essay in this volume, in which he questions the Darwinian Left and describes how it haunts Western political theory, is luckily not the only paper or essay available that questions the Darwinian Left. As we shall see, Darwinian Left is nothing more than an intellectual wasteland of myths and questionable scientific theories that many socialists and radicals (leftists) needed to add legitimacy to their thoughts and to prevent others from using Darwinism against them. That the Darwinian Left resurge today just shows how little leftists have understood parts of their intellectual heritage. 